\title{
Acotaciones a un artículo sobre Eduardo Mallea
}

En el Número 39 de la Revista Iberoamericana (Marzo de 1955) aparece un artículo sobre Eduardo Mallea en que aparte de varios juicios críticos harto discutibles, se hallan errores de hechos que urge rectificar si queremos impedir la creación de un Mallea apócrifo. Se trata sobre todo de la discusión de la novela Fiesta en noviembre, de la cual tengo a mano la segunda edición de la Editorial Losada (1949), que supongo no se diferencia mucho de la citada en el artículo. Sorprende por consiguiente que en éste se llame arquitecto al protagonista Lintas ( $p .135$ ) cuando en la novela aparece como pintor, y pintor que ha exhibido sus cuadros (pp. 53, 75, 94, $119,123)$. También consta en la novela que es a Lintas a quien se le pide un juicio sobre ciertas telas - lo cual da lugar a una escena culminante (pp. 91 y ss.) - y no el personaje secundario que se menciona en el artículo (p. 135). El asesinato de un poeta, que se nos asegura tiene lugar "en otra parte de la ciudad" y "en un parque solitario" (pp. 134-135) parece haberse confundido con otro asesinato -l de un librero- que refiere Lintas. Según la novela, la muerte del poeta ocurre fuera de cualquier ciudad (pp. 165-166); y aunque no se da indicación exacta del lugar ni del país, nada hay que justifique la aseveración del artículo, sobre todo cuando se tiene presente el epígrafe de Fiesta en noviembre.

En cuanto a las demás obras de Mallea, encontramos (p. 131) que La ciudad junto al rio inmóvil es "una serie de relatos que presentan una galería de mujeres" - calificación que da 
una idea poco exacta de un libro en que aparecen los protagonistas masculinos Durcal, Solves, Avesquín, Uber y Carlos Oro. Refiriéndose a Agata Cruz y a su marido ("Todo verdor perecerá) declara el artículo que ella "lo deja morir" (p. 136) dando así la impresión de un intento homicida de parte de Agata, cuando, al contrario, su deseo (aunque no cumplido) es suicidarse ella. Se puede comprobar esto leyendo las últimas páginas de la primera parte de la novela y también las primeras páginas de la segunda.

En las páginas 140 y 147 del citado artículo debe leerse "Roberto Ricarte" en vez de "Arturo Ricarte". La "Blanca" de la página 144 es la misma Blanche Alost que aparece en la tercera línea de esta página. "Azevedo" (léase "Acevedo"), si es joven, como lo asegura la página 143, será albino, ya que Mallea le presenta como hombre "de cabellos blancos" (La bahía de silencio, 3a. ed., 1950, p. 44). También es difícil que Mallea se escape de Amsterdam a Roma (p. 128) viajando "del sur al norte" (p. 123).

En la bibliografía con que concluye el artículo, aparte de una alfabetización un tanto caprichosa, debe advertirse que en los casos de Las Aguilas y Todo verdor perecerá solamente la primera fecha es la de la edición original, refiriéndose la segunda a una edición posterior. Tampoco estaría de más añadir la primera edición de Nocturno europeo (Buenos Aires: Sur, 1935). Las obras que ha publicado Mallea después de escrito el artículo en 1953 son Chaves (Buenos Aires: Losada, 1953), La sala de espera (Buenos Aires: Ed. Sudamericana, 1953) y Notas de un novelista (Buenos Aires: Emecé, 1954). El "estudio aparte" que pide la página 124 para las metáforas geográficas de Mallea se publicó en 1952. Véase Chapman, Arnold, "Terms of Spiritual Isolation in Eduardo Mallea", Modern Language Forum, XXXVII (No. 1-2, 1952), 21-27.

JoHN H. R. PoLT

University of California, Berkeley 